\title{
Measurement, Evolution, Determinants and Consequences of State Capacity: A Review of Recent Research
}

\begin{tabular}{|r|l|}
\hline Journal: & Journal of Economic Surveys \\
\hline Manuscript ID: & JOES-12-04-048.R2 \\
\hline Wiley - Manuscript type: & Original Article \\
\hline Date Submitted by the Author: & n/a \\
\hline Complete List of Authors: & $\begin{array}{l}\text { Savoia, Antonio; University of Manchester, IDPM } \\
\text { Sen, Kunal; University of Manchester, IDPM }\end{array}$ \\
\hline Abstract: & $\begin{array}{l}\text { State capacity, Governance, Economic development, Measurement, } \\
\text { Institutions }\end{array}$ \\
& $\begin{array}{l}\text { There is increasing realisation that state capacity is a fundamental } \\
\text { ingredient for effective governance, and is a crucial element of long-run } \\
\text { economic development. This paper offers an overview of the strengths and } \\
\text { limitations in current empirical research on the measurement of state } \\
\text { capacity. The paper also surveys the fast emerging literature on the } \\
\text { determinants and effects of state capacity. We argue that existing } \\
\text { measures on governance quality used in cross-national research can be } \\
\text { usefully exploited to capture different aspects of state capacity, and show } \\
\text { impost the end of the Cold War, developing economies have experienced } \\
\text { gap with advanced econoministrative and bureaucratic capacity, but the } \\
\text { the short temporal coverage of available measures of state capacity address } \\
\text { well as providing a systematic quantitative assessment of the determinants } \\
\text { of capacity and of its effects on development outcomes, such as health and } \\
\text { education, which have not received sufficient scrutiny. }\end{array}$ \\
\hline
\end{tabular}




\title{
Measurement, Evolution, Determinants and Consequences of State Capacity: A Review of Recent Research
}

\author{
Antonio Savoia (IDPM, University of Manchester) \\ Kunal Sen (IDPM, University of Manchester) ${ }^{i}$
}

$11^{\text {th }}$ February 2014

\begin{abstract}
There is increasing realisation that state capacity is a fundamental ingredient for effective governance, and is a crucial element of long-run economic development. This paper offers an overview of the strengths and limitations in current empirical research on the measurement of state capacity. The paper also surveys the fast emerging literature on the determinants and effects of state capacity. We argue that existing measures on governance quality used in cross-national research can be usefully exploited to capture different aspects of state capacity, and show that post the end of the Cold War, developing economies have experienced improvements in legal, administrative and bureaucratic capacity, but the gap with advanced economies is still wide. Future research should address the short temporal coverage of available measures of state capacity, as well as providing a systematic quantitative assessment of the determinants of capacity and of its effects on development outcomes, such as health and education, which have not received sufficient scrutiny.
\end{abstract}

\section{JEL Classification: 04, P5, N4}

Key-words: state capacity, governance, economic development, measurement, institutions. 


\section{Introduction}

For at least the last fifteen years, research on economic development has been engaging with aspects of economic governance, striving to estimate its causal effect on national income levels or growth rate. Although other development outcomes - such as inequality, health and education - have received far less attention, the current consensus is that improved governance leads to economic development. Most research so far has examined aspects of property rights security, but recent research in economics tends to view governance through the prism of the state. This literature, which builds on well-established literature on developmental states (e.g., Evans, 1995; Evans and Rauch, 1999; Herbst, 2000; and the collection of articles in Lange and Rueschemeyer, 2005), seems to increasingly recognise the importance of state capacity as a fundamental ingredient for effective governance.

So far, some have reassessed the role of the state as capable of overcoming coordination failures and as a provider of public goods (Bardhan, 2005 and Mosley, 2011), and have called for further analysis of state institutions. Others have advanced the theory of mechanisms leading to the formation effective states (Besley and Persson, 2009 and 2011; Acemoglu, Ticchi and Vindigni, 2011; Besley and Robinson, 2010) or to their collapse (e.g., Collier, 2009), or have analysed the likely trade-off between the high taxation of strong states and the under provision of public goods and infrastructure of states with limited capacity to tax (Acemoglu, 2005). While its analysis of the role of the state has a long and distinguished tradition, this paper contributes to its revival of interest by critically examining some aspects of the recent literature, mainly examining empirical issues, starting with the measurement of its most significant capacities. 
Empirical research can borrow measures of state capacity from the cross-national literature on governance quality. Building on the theory and practice of measuring governance quality, we review how, and how well, existing databases and measures capture state capacity: which aspects they measure; what and how robust the methodology is with respect to the hypotheses we want to test. Once identified, we shall see how such measures have been used. Therefore, we also offer a review of previous studies looking at the effect of the state on development outcomes and at the determinants of state capacity. Moreover, we shall use the available measures to illustrate its historical evolution, examining the trends of legal, bureaucratic and administrative capacities.

The paper proceeds as follows. Section 2 gives the background discussion on the definition and measurement of state capacity. Section 3 presents the most representative measures illustrating the evolution in the key dimensions of capacity. Section 4 reviews the literature on its effects and determinants. Section 5 concludes.

\section{Measuring State Capacity}

This section provides the background discussion and motivates the use of governance measurement in state capacity research. We need two building blocks. Firstly, we need to define the object of measurement and its dimensions. Secondly, aided by the debate on governance, we must discuss the methodological issues and the properties of state capacity measures. This precedes the illustration of a series of indicators, in section 3 , assessing how the key aspects of state capacity have evolved.

\subsection{State Capacities: Defining what to Measure}

State capacity can be defined as the institutional capability of the state to carry out various policies that deliver benefits and services to households and firms (Besley and 
Persson, 2011, p.2). ${ }^{\text {ii }}$ Its analysis is closely related to that of governance, as state capacity is one of its key aspects. Consider the World Bank's definition of governance as "the manner in which power is exercised in the management of a country's economic and social resources for development" (World Bank, 1992, p.1). iii Such definition fits a multiplicity of dimensions. And it may well include the power of the state and the quality of its institutions and policies, which historically plays a crucial role in the functioning of economies.

From this, identifying the object of measurement is not quite so straightforward. We must first consider how many functions the state should serve. Political and economic theories of the state differ tremendously on this matter. Traditionally, there has been no agreement where and how much the state should intervene in the economy. The pendulum may swing from one extreme to the other, depending also on the historical conditions (e.g., for an illustration of the various positions, see Stigler and Samuelson, 1968; Stiglitz, 1989). Similarly, to remain within the literature on economic development, the type of state capacity that promotes development may vary according to the proposed mechanisms through which the state affects development outcomes: some emphasising the protection of property rights (see Aron, 2000; and Tabellini, 2005); others pointing to the state involvement in overcoming coordination failures (e.g., Bardhan, 2005); or protecting specific economic sectors, supporting technological innovation, providing infrastructure and engaging in human capital formation (e.g., Evans, 1995). Consequently, the concept of state capacity must be dissected in order to identify the measures that are best aligned with it. It is perhaps appropriate to map state capacities according to the functions the state performs. A plausible list would start with:

- Bureaucratic and administrative capacity. Whatever we may maintain a state should do to foster development, it needs a bureaucratic apparatus to design and implement policies. This dimension is central to all areas of research on state and development, and 
it is related to the ability of spending the tax proceeds efficiently on public goods (Acemoglu et al. 2011). Traditionally, state capacity indicators would focus on the competence and ability of bureaucracy (e.g., Evans and Rauch, 1999, Rauch and Evans, 2000).

- Legal capacity: the capability of enforcing contracts and property rights (i.e., a judicial system for settling disputes, rule of law). The consensus is that, at the very least, the state has to provide such public goods, as they are ill-suited to private provision (Besley and Persson, 2009 and 2011; Lin and Nugent, 1995; Collier, 2009).

- Infrastructural capacity. This refers to the territorial reach of the state, the extent to which control can be exercised over the territory, i.e., the geographical area within which policies can be enforced (see Soifer, 2008; Mann, 2008; Soifer and Vom Hau, 2008).

- Fiscal capacity is the state's ability to raise revenues from taxes and is closely linked to the emergence of bureaucratic and administrative capacity (see Besley and Persson, 2009 and 2011; Acemoglu et al. 2011).

- Military capacity refers to the state's ability to deter or repel challenges to its authority with force, so facing issues of internal and external security. It has mainly concerned civil conflict scholars, who argue that an increase in police and military forces can repress insurgent groups (e.g. Hendrix, 2010). But recent research on state formation is looking at the conditions under which the military can effectively establish the state's monopoly of violence while minimising risks of coups or civil wars (Besley and Robinson, 2010; Acemoglu et al. 2010a; Acemoglu et al. 2010b).

The set of capacities listed above, without implying its exhaustiveness, constitute a starting point. Because of the attention received in the empirical literature, but without considering 
them priors, the discussion will focus mainly on examples of legal, bureaucratic and administrative capacity. On the other hand, improvements in these types of capacities may be complementary and reinforce the establishment of state authority over the territory, promote taxation, military defence, the provision of public goods and market intervention.

\subsection{Methodological issues}

Empirical research on governance quality has designed numerous and diverse measures which are suitable to capture aspects of state capacity: the protection of property rights; quality and performance of the bureaucracy; the administration of justice; as well as micro and macroeconomic management. ${ }^{\text {iv }}$ Therefore, we can use and adapt the methods and findings from such literature to the case of state capacity.

A popular classification divides governance indicators in objective and subjective measures (e.g., see Williams and Siddiqui, 2008). ${ }^{\mathrm{V}}$ Examples of measures constructed from hard data try to capture political instability and violence using historical records of political assassinations, riots, demonstrations and so forth from Banks (1994). Such measures are imperfect proxies of governance and current research has not often used them (see Williams and Siddiqui, 2008 and references therein). Coming to the theme of state capacity, a relevant example of objective measure is the use of government revenue as a percentage of GDP, as a proxy of fiscal capacity. There are a number of limitations to this approach: (i) it seems to be an outcome of state capacity, rather than an assessment of its quality; (ii) it is constructed from macroeconomic variables that may fluctuate with the cycle, thus recording a change in state capacity when instead the state apparatus has not been reformed; (iii) such a proxy may reflect the role of national culture and values, where citizens tend to evade taxes less, rather than state capacity itself. The literature on tax evasion has argued, and provided evidence, 
that agents may follow moral norms and so be more inclined to pay taxes (see Slemrod, 2007).

A second class of objective measures are rule-based, i.e., constructed by rating the existence and strength of certain formal (de jure) rules. Alternatively, subjective measures are perception-based, i.e., ratings rely on perceptions of the de facto functioning of rules, coming from: (i) experts' opinions, e.g., risk-rating agencies, foreign investors, academics or NGOs; and (ii) surveys of national respondents (firms or individuals). Surveys have the advantage of capturing the views of domestic agents directly involved in the institutions of the country, but are more expensive to administer (and hence less likely to be repeated) and less suitable for cross-country comparability than expert assessments. Measures from the World Governance Indicators (WGIs), by Kaufmann et al. (2009), combine both types of subjective information from either experts or surveys, while the ICRG (1997) and Fraser Institute property rights measures (Gwartney and Lawson, 2007) rely on the perceptions of experts. Which types of measures have the best properties? In terms of the type of methodology, the advantage of rules-based indicators is that they are free from political or ideological biases that, say, experts' assessments may have. In addition, such measures have the advantage of synthesising many and diverse formal institutional and policy elements into one single aggregate governance index. However, they could well be vulnerable to gaps between the essence of rules on codes and how they function on the ground (e.g., bribes can be codified as illegal, but no anticorruption agency exists). Hence, perception-based measures should be sensitive to any institutional and policy change: both formal and informal.

An additional limitation, which perhaps applies to all subjective indicators, is that in practice they do not indicate which specific policy intervention is actually responsible for observed changes in governance quality or state capacity. Perception-based measures could be particularly prone to this problem. Since this is a popular example, let us consider the 
ICRG and Fraser Institute measures used to express the degree of property rights protection. Each of their subcomponents is, in principle, different (and could be correlated with different intensity and direction to development outcomes). There is no compelling reason to believe that, for instance, a policy intervention aimed at improving the rule of law affects other aspects of state capacity, such as the recruitment of bureaucrats. This may or may not happen, depending on the actual policy. Yet, the correlations amongst each of these subcomponents show that all sub-indices are highly and positively correlated among themselves (table 1).

\begin{tabular}{|c|c|c|c|c|c|c|}
\hline \multicolumn{7}{|c|}{ Panel a: correlation among Fraser property rights components } \\
\hline & $\begin{array}{l}\text { Property rights } \\
\text { (Fraser) }\end{array}$ & $\begin{array}{l}\text { Judicial } \\
\text { Independence }\end{array}$ & Impartial courts & Property rights & $\begin{array}{l}\text { Military in } \\
\text { politics }\end{array}$ & Rule of law \\
\hline Property rights (Fraser) & 1.00 & & & & & \\
\hline Judicial Independence & $0.92 *$ & 1.00 & & & & \\
\hline Impartial courts & $0.90^{*}$ & $0.92 *$ & 1.00 & & & \\
\hline Property rights & $0.89^{*}$ & $0.85^{*}$ & $0.84 *$ & 1.00 & & \\
\hline Military in politics & $0.85^{*}$ & $0.67 *$ & $0.69 *$ & $0.63^{*}$ & 1.00 & \\
\hline Rule of law & $0.85^{*}$ & $0.71 *$ & $0.64 *$ & $0.71 *$ & $0.64 *$ & 1.00 \\
\hline Property rights (ICRG) & $0.89 *$ & $0.81 *$ & $0.79 *$ & $0.78^{*}$ & " $0.81 *$ & $0.73 *$ \\
\hline \multicolumn{7}{|c|}{ Panel b: correlation among ICRG property rights components } \\
\hline & $\begin{array}{l}\text { Property rights } \\
\text { (ICRG) }\end{array}$ & $\begin{array}{l}\text { Bureaucratic } \\
\text { Quality }\end{array}$ & Rule of law & $\begin{array}{l}\text { Corruption in } \\
\text { Government }\end{array}$ & $\begin{array}{l}\text { Expropriation } \\
\text { risk }\end{array}$ & $\begin{array}{l}\text { Government } \\
\text { repudiation of } \\
\text { contracts }\end{array}$ \\
\hline Property rights (ICRG) & 1.00 & & & & & \\
\hline Bureaucratic Quality & $0.90^{*}$ & 1.00 & & & & \\
\hline Rule of law & $0.92 *$ & $0.77 *$ & 1.00 & & & \\
\hline Corruption in Government & $0.85^{*}$ & $0.79^{*}$ & $0.74 *$ & 1.00 & & \\
\hline Expropriation risk & $0.89 *$ & $0.69^{*}$ & $0.80 *$ & $0.62 *$ & 1.00 & \\
\hline Government repudiation of contracts & $0.91 *$ & $0.75^{*}$ & $0.79 *$ & $0.65^{*}$ & $0.90^{*}$ & 1.00 \\
\hline "Property rights (Fraser) & $0.89 *$ & $0.81 *$ & $0.90 *$ & $0.76^{*}$ & $0.78^{*}$ & $0.78 *$ \\
\hline
\end{tabular}

This suggests that policy intervention in one area might be perceived as improving the general governance environment, in which case we infer that perception-based indices might have limited power in distinguishing different attributes of governance. However, the correlations in table 1 alternatively also suggest that there are relevant complementarities amongst dimensions of governance (as argued in Besley and Persson, 2011), in which case subjective measures would correctly record a simultaneous change in all the components.

Despite the potential limitations, there is scope for using subjective assessments: having a wider range of measures can only increase the number of questions that empirical research can address. Researchers must carefully choose the appropriate measure or use more 
than one measure in conjunction, if the concept of governance under scrutiny requires so. To this aim, table 2 summarises types and properties of governance measures.

\begin{tabular}{|c|c|c|c|}
\hline Type of measure & Obje & ective & Subjective \\
\hline based on: & Proxies from hard data & De jure rules & De facto rules \\
\hline Advantages & Not affected from observer's bias & $\begin{array}{l}\text { Not affected from observer's bias; } \\
\text { isolate specific governance } \\
\text { dimensions }\end{array}$ & $\begin{array}{l}\text { Capturing formal and informal } \\
\text { rules }\end{array}$ \\
\hline Limitations & $\begin{array}{l}\text { At best expressing outcomes of } \\
\text { governance; do not address specific } \\
\text { governance aspect }\end{array}$ & $\begin{array}{l}\text { May not capture the functioning of } \\
\text { informal mechanisms }\end{array}$ & $\begin{array}{l}\text { Affected from observer's bias; } \\
\text { unable to isolate specific } \\
\text { governance dimensions }\end{array}$ \\
\hline
\end{tabular}

Having provided an overview of the methodological issues, we finish the section with

some remarks on the construction of a composite index, which would capture diverse capacities. If the purpose is mainly research, a database of measures of state capacity does not necessarily have to provide a synthetic index. It would be debatable how many dimensions should be part of a composite index. Even if one could reach a consensus on which dimensions should be included, we would still be left with the task of elaborating an appropriate formula to aggregate the would-be components. For example, should it be additive? Multiplicative? This can only be decided on the basis of further theoretical foundations. Meanwhile, researchers should be able to use disaggregated measures: addressing specific research questions may require combining measures in a different fashion each time. From this, it follows that a useful property of any state capacity (or governance) index is to make its components available. Bearing this in mind, a composite index, while not always indispensable for academic research, would be useful to policy makers. To this aim, some institutions have designed general measures, inspired by the literature on state failure. Such indices are aimed at capturing conditions when the state apparatus does not command one or more of its capacities and hence cannot deliver its core functions. An excellent guide is UNDP (2009). The working paper version of this article (Savoia and Sen, 2012) gives three examples of state fragility indices, chosen because of their extensive coverage of countries and time. Apart from the political stability and absence of violence index by Kaufmann et al. 
(2009), which concentrates on the likelihood of conflict, the others have among their components variables that should result as outcomes of state capacity (e.g., GDP).

While governance literature provides a number of variables to research state capacity, the proposed measures are subject to the same methodological disputes. However, such plurality of indicators and databases is beneficial to future research. Different measures capture distinct aspects of state capacity. However, they should not be necessarily considered interchangeable (for the purpose, say, of conducting robustness checks). Instead, they should be carefully selected depending on the type of development outcome one wishes to study, as recently demonstrated in Cheibub, Gandhi and Vreeland (2010) regarding political regime measures. On the other hand, if one believes that there could be complementarities among different elements of state capacity, further discussion on a composite measure combining the different aspects of state capacity would have greater scope.

\section{The evolution of state capacity: measures and some statistics}

What are the available measures? Efforts to provide comparable governance and state capacity measures face either the constraint of limited country coverage or of time coverage. Here we focus on the most representative measures, to offer some statistics. Savoia and Sen (2012), however, give a broader overview of the available databases and measures (as well as a list of countries observed). Empirical studies have mostly focussed on the variation across countries. Here, instead, we illustrate the trends over time.

The IRIS database, constructed by Knack and Keefer (1995) from International Country Risk Guide data (ICRG, 1997), covers 145 countries over the 1985-1997 period. Its variables are the most commonly used measures of institutional quality in the empirical literature on institutions and development (e.g., Acemoglu, Johnson and Robinson, 2001; Knack and Keefer, 1995). The data comes from subjective assessments of foreign investors 
and business experts. It includes the government repudiation of contracts, the expropriation risk, rule of law, corruption in government, and bureaucratic quality indices. The first three are indicators of legal capacity of the state; the last two capture the level of bureaucratic and administrative capacity.

Given its most extensive geographical coverage stretching over two hundred countries, influential articles on governance and development (e.g. Rodrik et al., 2004) have also utilised data from WGIs (World Bank, 2011). Four (out of six) indicators may be seen as proxies for state capacity: rule of law, regulatory quality and government effectiveness, as well as control of corruption. The first three variables express the degree of legal and administrative capacity. The remaining one is a proxy for bureaucratic capacity. These are all subjective measures that try to improve on country coverage by aggregating the ratings from over thirty organisations. Unfortunately, the period covered only goes from 1996 onward.

State capacity is a slow-changing phenomenon and it should be analysed over a longer period. Hence, we concentrate on two further databases that, measuring similar dimensions of governance quality, allow to observe the longest period: the Quality of Government index assembled by Teorell et al. (2008) and the Quality of Legal Structure and Security of Property Rights index (Gwartney and Lawson, 2007). The Quality of Government index extends the IRIS database, but focuses only on three of its variables. In fact, it is calculated as the average of rule of law, corruption in government, and bureaucratic quality indices from various editions of the International Country Risk Guide (the other two components seen above were discontinued after 1997). It spans from 1984 to 2008 and is rescaled to lie between 0 and 1. The Quality of the Legal Structure and Security of Property Rights is, instead, a useful proxy for legal capacity. A component of the Fraser Institute index of Economic Freedom, such variable is continuous and ranges between 1 and 10, with a higher score corresponding to higher quality. It is available over the longest time span, also 
for a number of developing economies. It has, in fact, been recorded every five years from 1970 until 2000 (and every year from 2001 on), but between 1970 and 1975 only fifty countries are observed. Unfortunately, it samples fewer countries than the ICRG database. Such index has been assembled over the years from different sources - essentially, but not exclusively, from: the ICRG, the Business Environment Risk Intelligence and the Global Competitiveness Report - and has undergone some changes in definition, although the underlying concept remains unchanged (see, for details, Gwartney and Lawson, 2007).

\begin{tabular}{|c|c|c|c|c|c|c|c|c|}
\hline \multicolumn{9}{|c|}{$\begin{array}{l}\text { Table 3: Governance quality the world around: } 1980-2009 \\
\text { Panel (a): Ouality of legal structure and security of property rights index }\end{array}$} \\
\hline \multicolumn{2}{|l|}{ Year } & \multirow{2}{*}{$\begin{array}{l}1980 \\
5.01 \\
0.40 \\
90\end{array}$} & \multirow{2}{*}{$\begin{array}{l}1985 \\
5.09 \\
0.36 \\
110\end{array}$} & \multirow{2}{*}{\begin{tabular}{|l|}
1990 \\
5.31 \\
0.36 \\
111
\end{tabular}} & \multirow{2}{*}{$\begin{array}{l}1995 \\
5.87 \\
0.29 \\
123\end{array}$} & \multirow{2}{*}{$\begin{array}{l}2000 \\
5.83 \\
0.33 \\
123\end{array}$} & \multirow{2}{*}{$\begin{array}{l}2005 \\
5.85 \\
0.30 \\
139\end{array}$} & \multirow{2}{*}{$\begin{array}{l}2009 / 2008 \\
5.62 \\
0.28 \\
139\end{array}$} \\
\hline Whole sample & $\begin{array}{l}\text { Mean } \\
\mathrm{CV} \\
\mathrm{N}\end{array}$ & & & & & & & \\
\hline Advanced Economies & $\begin{array}{l}\text { Mean } \\
\mathrm{CV} \\
\mathrm{N}\end{array}$ & $\begin{array}{l}7.19 \\
0.13 \\
28\end{array}$ & $\begin{array}{l}7.05 \\
0.18 \\
30\end{array}$ & $\begin{array}{l}7.55 \\
0.15 \\
30\end{array}$ & $\begin{array}{l}8.18 \\
0.13 \\
30\end{array}$ & $\begin{array}{l}8.34 \\
0.14 \\
30\end{array}$ & $\begin{array}{l}8.17 \\
0.11 \\
30\end{array}$ & $\begin{array}{l}7.63 \\
0.12 \\
30\end{array}$ \\
\hline Developing Economies & $\begin{array}{l}\text { Mean } \\
\mathrm{CV} \\
\mathrm{N} \\
\end{array}$ & $\begin{array}{l}4.03 \\
0.36 \\
62 \\
\end{array}$ & $\begin{array}{l}4.19 \\
0.31 \\
73 \\
\end{array}$ & $\begin{array}{l}4.27 \\
0.32 \\
74\end{array}$ & $\begin{array}{l}4.98 \\
0.22 \\
78 \\
\end{array}$ & $\begin{array}{l}4.87 \\
0.27 \\
78 \\
\end{array}$ & $\begin{array}{l}5.05 \\
0.28 \\
86 \\
\end{array}$ & $\begin{array}{l}4.85 \\
0.26 \\
86 \\
\end{array}$ \\
\hline Transition Economies & $\begin{array}{l}\text { Mean } \\
\mathrm{CV} \\
\mathrm{N} \\
\end{array}$ & & $\begin{array}{l}5.95 \\
0.21 \\
7 \\
\end{array}$ & $\begin{array}{l}6.46 \\
0.13 \\
7\end{array}$ & $\begin{array}{l}5.90 \\
0.19 \\
15 \\
\end{array}$ & $\begin{array}{l}5.82 \\
0.14 \\
15 \\
\end{array}$ & $\begin{array}{l}5.73 \\
0.17 \\
23 \\
\end{array}$ & $\begin{array}{l}5.74 \\
0.13 \\
23 \\
\end{array}$ \\
\hline \multicolumn{9}{|c|}{ Panel (b): Quality of Government index } \\
\hline Whole sample & $\begin{array}{l}\text { Mean } \\
\mathrm{CV} \\
\mathrm{N}\end{array}$ & & $\begin{array}{l}0.53 \\
0.48 \\
120\end{array}$ & $\begin{array}{l}0.53 \\
0.47 \\
127\end{array}$ & $\begin{array}{l}0.63 \\
0.35 \\
127\end{array}$ & $\begin{array}{l}0.57 \\
0.37 \\
138\end{array}$ & $\begin{array}{l}0.53 \\
0.39 \\
138\end{array}$ & $\begin{array}{l}0.53 \\
0.38 \\
138\end{array}$ \\
\hline Advanced Economies & $\begin{array}{l}\text { Mean } \\
\mathrm{CV} \\
\mathrm{N}\end{array}$ & & $\begin{array}{l}0.86 \\
0.19 \\
29\end{array}$ & $\begin{array}{l}0.85 \\
0.20 \\
30\end{array}$ & $\begin{array}{l}0.92 \\
0.09 \\
30\end{array}$ & $\begin{array}{l}0.86 \\
0.14 \\
30\end{array}$ & $\begin{array}{l}0.85 \\
0.14 \\
30\end{array}$ & $\begin{array}{l}0.84 \\
0.13 \\
30\end{array}$ \\
\hline Developing Economies & $\begin{array}{l}\text { Mean } \\
\mathrm{CV} \\
\mathrm{N}\end{array}$ & & $\begin{array}{l}0.41 \\
0.44 \\
80\end{array}$ & $\begin{array}{l}0.41 \\
0.41 \\
86\end{array}$ & $\begin{array}{l}0.52 \\
0.29 \\
86\end{array}$ & $\begin{array}{l}0.47 \\
0.29 \\
87\end{array}$ & $\begin{array}{l}0.42 \\
0.30 \\
87\end{array}$ & $\begin{array}{l}0.43 \\
0.29 \\
87\end{array}$ \\
\hline Transition Economies & $\begin{array}{l}\text { Mean } \\
\mathrm{CV} \\
\mathrm{N}\end{array}$ & & $\begin{array}{l}0.54 \\
0.29 \\
11\end{array}$ & $\begin{array}{l}0.61 \\
0.21 \\
11\end{array}$ & $\begin{array}{l}0.69 \\
0.21 \\
11\end{array}$ & $\begin{array}{l}0.55 \\
0.28 \\
21\end{array}$ & $\begin{array}{l}0.51 \\
0.23 \\
21\end{array}$ & $\begin{array}{l}0.51 \\
0.23 \\
21\end{array}$ \\
\hline $\begin{array}{l}\text { Notes: data is from Qw } \\
\text { calculated keeping the } s \\
\text { system: based on per ca } \\
\text { (http://www.imf.org/ext }\end{array}$ & $\begin{array}{l}\text { ey and I } \\
\text { ple size } \\
\text { income } \\
\text { al/pubs/ }\end{array}$ & $\begin{array}{l}\text { el, export } \\
\text { eo/2011/0 }\end{array}$ & $\begin{array}{l}\text { Teore } \\
\text { the in } \\
\text { arsificat }\end{array}$ & $\begin{array}{l}2008) . \\
r \text { and c } \\
\text { degree } \\
\text { htm, ac }\end{array}$ & $\begin{array}{l}\text { ids are } \\
\text { over til } \\
\text { ration } \\
\text { i } 25 / 8\end{array}$ & $\begin{array}{l}\text { ailar al } \\
\text { atries' } \\
\text { global }\end{array}$ & $\begin{array}{l}\text { the sa } \\
\text { ation } \mathrm{f} \\
1 \text { syste }\end{array}$ & $\begin{array}{l}\text { tics are } \\
\text { le IMF }\end{array}$ \\
\hline
\end{tabular}

Table 3 shows the trends in advanced, developing and transition economies over

1980-2009. The first stylised fact is the gap in governance quality between advanced economies and the rest remains wide. Since the 1980s, both developing and advanced economies have, by the end of the observed period, experienced improvements in the Quality of Legal Structure and Security of Property Rights (which were relatively larger in developing economies). The Quality of Government index, instead, remained essentially 
stable in both advanced and developing countries over the period. The transition economies experienced deterioration in governance quality, according to both measures.

As a second stylised fact, it is noteworthy that the cross sectional dispersion (as expressed by the coefficient of variation) over the whole sample, from the beginning to the end period, decreases in both measures. However, the decrease is monotonic in both measures until the end of the Cold War, but subsequently the dispersion picks up again or becomes stable, so suggesting that a likely convergence effect in governance quality has stopped or decelerated. Along both measures, advanced economies remain a more homogenous group than developing and transition economies, which show greater variability in governance quality at the end of the period.

Figure 1 below provides further details by disaggregating the developing countries group by region. The end of the Cold War was accompanied by sharp improvements in governance quality, suggesting that it has been a positive shock for governance quality. Quality of Government shows a spike for all groups of countries in the mid 1990s, where all regions of the developing world seem to move closer to the advanced economies. But the subsequent worsening slows this process, although some convergence seems to have occurred. The Quality of Legal Structure and Security of Property Rights presents a similar evolution across regions. The group of countries that has improved governance quality most compared to its initial level is the MENA region (followed by Latin America), in terms of the Quality of Legal Structure and Security of Property Rights, and Asia (followed by Latin America), in terms of the Quality of Government. Note also that in both cases the transition economies have experienced a significant decrease in governance quality after the end of the Cold War. 

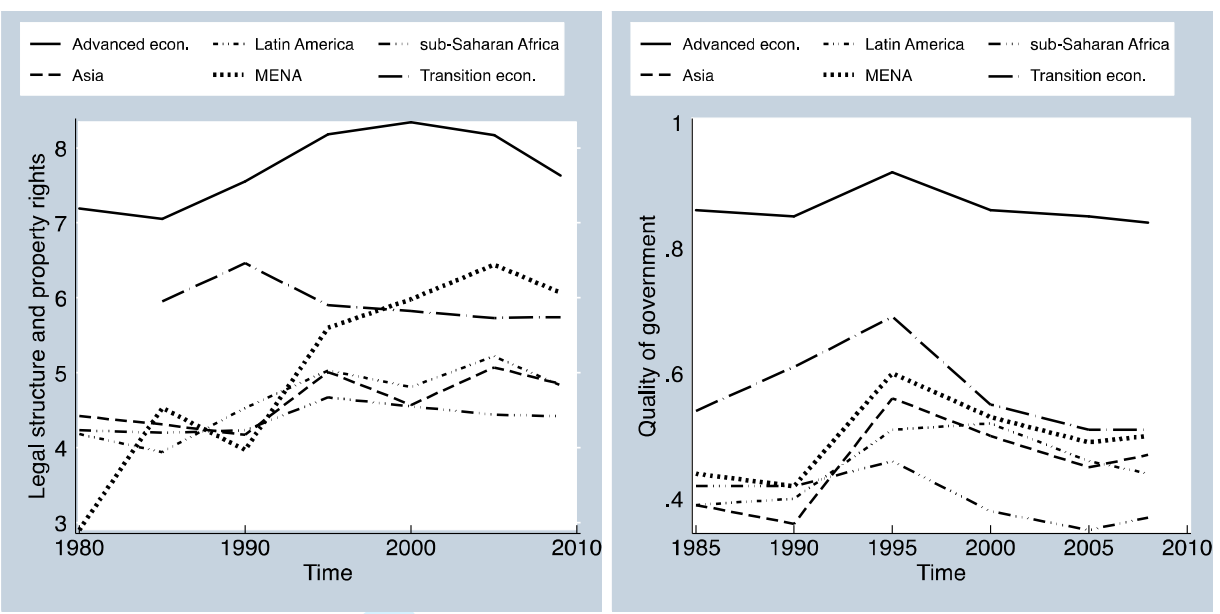

Figure 1 - Governance quality time paths by level of development

Apart from providing some stylised facts, the evidence presented in this section illustrates the difficulties faced by empirical research on state capacity (and governance alike). There is a trade-off between the number of countries and number of years observed. Even the richest governance databases, presented above, force researchers to choose between temporal and geographical dimensions. The time dimension is particularly problematic. Changes in state capacity originate from institutional changes. These are long-run phenomena that are best observed with measures spanning many decades back in time.

\section{Effects and determinants of state capacity: what do we know?}

This section reviews the subset of governance literature intersecting with the literature on state capacity. We first give a brief account of the empirical literature that has used governance measures expressing aspects of state capacity (such as the above measures) to estimate their effects on development outcomes, including some econometric considerations on this research. The second task of this section is to review the literature on the determinants of state capacity. 


\subsection{State capacity and development outcomes}

Does state capacity matter for development? What has the empirical literature found? Table 6 summarises recent contributions focussing on state capacity aspects, and which have used some of the measures reviewed here, to explain a series of development outcomes.

Most studies aimed at explaining economic growth and national income levels. These are by far the outcomes that have received the most scrutiny, of which thorough reviews already exist (see Tabellini, 2005; and Aron, 2000). Despite the high level scrutiny received, it is still unclear whether the high correlation between property rights institutions and national income levels results from reverse causation (in the case of economic growth, the correlation is not always robust). Future research should, however, focus more on the multiple facets of state capacity. Therefore, table 4 reports two articles that refer to the effects of administrative and fiscal capacities (Rauch and Evans, 1999; Dincecco and Prado, 2013).

Most of the space in table 4 is, instead, devoted to illustrate what type of effects the empirical literature has found with respect to other, and equally important, economic outcomes. Two recent studies find contrasting results regarding the role of bureaucratic quality and the level of aggregate investments (Cavallo and Daude, 2011; Keefer and Knack, 2007). Two other articles unanimously find that economies with institutional deficiencies are more prone to economic crises, despite the role of macroeconomic policies (Acemoglu et al., 2003; Du, 2010).

Classic development outcomes, such as inequality and poverty, have received scant attention. The results so far seem to indicate that the effects on income distribution may be nonlinear, while higher state capacity has been associated with lower poverty levels. Perhaps the literature considering the effects on human capital formation has received even less scrutiny so far, with Dawson (2010) looking at child mortality and Baikumar and Swaroop 
(2008) looking at some health and education attainments. Finally, not reported in table 4, there is a separate literature on conflict research, which has tried to demonstrate that strong states have decreased risk of civil war (see Sobek, 2010).

\begin{tabular}{|c|c|c|c|}
\hline Author(s) and year & $\begin{array}{l}\text { Countries and Time } \\
\text { frame }\end{array}$ & $\begin{array}{l}\text { Econometric } \\
\text { methods }\end{array}$ & Findings \\
\hline \multicolumn{4}{|l|}{ National income } \\
\hline Rauch and Evans (1999) & $\begin{array}{l}\text { Cross-section of } 35 \\
\text { less developed } \\
\text { countries, 1970-1990 }\end{array}$ & OLS & $\begin{array}{l}\text { State bureaucracies characterised by meritocratic } \\
\text { recruitment and predictable, rewarding career } \\
\text { ladders are associated with higher growth rates. }\end{array}$ \\
\hline Dincecco and Prado (2013) & $\begin{array}{l}\text { Cross-section of } 96 \\
\text { countries }\end{array}$ & OLS and IV & $\begin{array}{l}\text { Variation in fiscal capacity (as a result of pre- } \\
\text { modern wars) explains long-run productivity levels } \\
\text { (GDP per worker), once accounting for endogeneity. }\end{array}$ \\
\hline Investment & V & & \\
\hline Cavallo and Daude (2011) & $\begin{array}{l}\text { Panel, 1980- 2006, } \\
116 \text { developing econ. }\end{array}$ & GMM-IV & $\begin{array}{l}\text { Public investment crowding-out effect is smaller or } \\
\text { even reversed where bureaucracies and rule of law } \\
\text { are stronger. }\end{array}$ \\
\hline Keefer and Knack (2007) & \begin{tabular}{|l|}
$\begin{array}{l}\text { Cross-section, } 114 \\
\text { countries }\end{array}$ \\
\end{tabular} & OLS and IV & $\begin{array}{l}\text { Public investment levels are higher where property } \\
\text { rights are weaker and corruption is higher. }\end{array}$ \\
\hline \multicolumn{4}{|l|}{ Economic crises } \\
\hline $\mathrm{Du}(2010)$ & $\begin{array}{l}\text { Cross-section and } \\
1970-1999 \text { panel, } 69 \\
\text { countries }\end{array}$ & $\begin{array}{l}\text { OLS and } \\
\text { Probit }\end{array}$ & $\begin{array}{l}\text { Historical institutions (reflected in the legal origins } \\
\text { and settler mortality) predict the occurrence and } \\
\text { intensity of currency and real crises better than time- } \\
\text { varying institutions do. }\end{array}$ \\
\hline Acemoglu et al (2003) & $\begin{array}{l}\text { Cross-section and } \\
1970-1999 \text { panel, } 64 \\
\text { ex-colonies }\end{array}$ & OLS and IV & $\begin{array}{l}\text { Exchange rates are less misaligned, inflation and } \\
\text { budget deficits are smaller in systems where } \\
\text { governments are held accountable, via political } \\
\text { checks and balances, and there is effective property } \\
\text { rights enforcement and less corruption. }\end{array}$ \\
\hline \multicolumn{4}{|l|}{ Income distribution } \\
\hline Amendola et al (2013) & $\begin{array}{l}\text { Cross-section and } \\
\text { panel 1970-2004, } 47 \\
\text { developing countries }\end{array}$ & $\begin{array}{l}\text { OLS and } \\
\text { LSDVC }\end{array}$ & $\begin{array}{l}\text { Property rights increase income inequality, but the } \\
\text { effect is smaller in democracies. }\end{array}$ \\
\hline Chong and Calderon (2000) & $\begin{array}{l}\text { Cross-section, } 70 \\
\text { countries }\end{array}$ & OLS and IV & $\begin{array}{l}\text { Evidence of a hump-shaped relationship with legal } \\
\text { and bureaucratic capacity. }\end{array}$ \\
\hline \multicolumn{4}{|l|}{ Poverty } \\
\hline Chong and Calderon (2000) & $\begin{array}{l}\text { Cross-section, } 49 \\
\text { countries }\end{array}$ & OLS and IV & $\begin{array}{l}\text { Improvements in ICRG measures reduce the degree, } \\
\text { severity and incidence of poverty. }\end{array}$ \\
\hline Tebaldi and Mohan (2010) & $\begin{array}{l}\text { Cross-section, } 107 \\
\text { countries }\end{array}$ & OLS and IV & $\begin{array}{l}\text { Improvements in the WGIs reduce poverty levels via } \\
\text { economic growth. }\end{array}$ \\
\hline \multicolumn{4}{|l|}{ Health \& Education } \\
\hline Dawson (2010) & $\begin{array}{l}\text { Panel, } 93 \text { countries, } \\
1990-2005\end{array}$ & LSDV & $\begin{array}{l}\text { Stronger rule of law decrease child mortality. Fiscal } \\
\text { capacity has no significant effect. }\end{array}$ \\
\hline $\begin{array}{l}\text { Raikumar and Swaroop } \\
(2008)\end{array}$ & $\begin{array}{l}\text { Panel, } 91 \text { countries, } \\
1990-2003\end{array}$ & OLS & $\begin{array}{l}\text { Public spending has no effect on health and } \\
\text { education in countries with worse bureaucracies and } \\
\text { corruption. }\end{array}$ \\
\hline \multicolumn{4}{|l|}{ Happiness } \\
\hline $\begin{array}{l}\text { Bjørnskov, Dreher and } \\
\text { Fischer (2010) }\end{array}$ & Panel, 62 countries & OLS & $\begin{array}{l}\text { Higher WGIs and better legal system are associated } \\
\text { with improvements in self-reported well-being. }\end{array}$ \\
\hline
\end{tabular}

The rest of this section discusses some econometric issues that research design has not

always addressed. Regarding the econometric strategy, as a result of the availability of comparable units of analysis, most studies use national-level data to assess the influence of key governance variables on economic performance. The most used econometric approach 
relied on cross-section methods. To handle reverse causality and omitted variable problems, the challenge has been to identify the effect of governance by constructing instrumental variables and natural experiments. While this is appropriate, as the underlying relationships of interest have long-run nature, in practice it is not easy to justify the validity of instruments and history does not always provide natural experiments.

However, findings from econometric analyses at cross-country level have limitations below national levels of analysis. In many respects, developing countries exhibit a high degree of heterogeneity, thus national level trends may not reflect distinctive developments that may take place at the subnational or regional level. Focusing on the case of India, the work by Besley and Burgess (2002), Banerjee and Iyer (2005) and Calì and Sen (2011) have offered useful insights into the political economy of governance and development of subnational units. But in general, research at subnational level is impaired by the fact that there are no ready-made governance measures.

In principle, panel data methods (with $\mathrm{N}$-greater-than- $\mathrm{T}$ so far) could facilitate handling endogeneity and dealing with heterogeneity. However, such an approach in practice is still constrained by data limitations. Governance quality is a persistent phenomenon. Sharp changes are unlikely, as they involve changes within the institutional framework that in turn bear distributive consequences that the ruling class will resist. Therefore, it should be observed and analysed over the long run. Available measures, also covering a large sample of countries, only go back the last thirty years. Unfortunately, there is no measure of economic governance going further back in time that would have substantial time series variation. This issue should be addressed by future research on governance. Political scientists have constructed measures of political democracy, instead, stretching as far back as the beginning of the $19^{\text {th }}$ century (see Munck and Verkuilen, 2002). There is a lot to gain from similar research efforts in the future: for example, creating a database that, exploiting comparative 
historical analysis, brings temporal depth to some governance measures. Meanwhile, empirical research on the role of the state, whether at the national or subnational level, has to make the best possible use of the available governance measures.

In addition, most governance databases do not include a non-trivial number of developing economies, which could instead be very relevant for questions on the effects of governance on economic development. Apart from the WGIs, available governance measures, especially those produced by political risk consultancies, are not immune to this criticism. It is perhaps also true that recent updates of governance measures observe a larger sample of countries, which is more likely to be representative. Econometric research can face this by explicitly addressing sample selection problems.

Finally, as Kauffmann and Kraay (2008) have stressed, governance measures can be subject to measurement error. It is well understood in regression analysis what the consequences are for parameter estimates of errors in variables from the "left" and from the "right". However, empirical papers should explicitly comment on this problem, so shedding further light on the relevance of the findings.

\subsection{Determinants of state capacity}

Since the studies above highlight the role of state capacity for development outcomes, we should also look at the conditions under which certain states develop higher capacity. There are three broad groups of determinants, related to historical, geographical or political economy explanations. Borrowing also from the scholarship on institutional development, here we review the main ideas and the related evidence. The literature has inevitably concentrated on the long run determinants of state capacity. We begin with the group focusing on historical factors: 
- Length of statehood. Bockstette, Chanda and Putterman (2002) have suggested, and constructed ad hoc variables, that state history could be important for state capacity. Their state antiquity index is based on the plausible intuition that longer histories of statehood lead to higher quality administration due to 'learning by doing' effects. They also show that state antiquity is a good instrument for institutional quality in regressions that aim to explain long-run development. A measure for the antiquity of the state is constructed for 149 countries by observing their state history over the period from 1 to 1950 A.C. For each 50-year period, each country has been allocated a score for the existence of a government above tribal level; whether the government is locally based or foreign; and how much of the territory of the modern country was ruled by this government. The scores for each 50 -year sub-period have been multiplied by one another and then summed by weighting down the periods in the more remote past. Future research can exploit this variable to address econometric problems due to reverse causality and omitted variables.

- External conflict. A strand of historical research on state formation emphasise the role of external conflicts, which seemed to be important for Western states (see Spruyt, 2002, p.135-137), although less so for Latin America (Centeno, 2002). In line with this tradition, Besley and Persson (2009), argue that, in a society where groups compete for power, the incidence of wars supports the demand for common-interest public goods (i.e., defence) that, in turn, increases the incentive to invest in fiscal and legal capacity. They also explore some conditional correlations between some aspects of state capacity and the determinants suggested by the literature, finding cross-section evidence supporting this idea. Related to this argument, Herbst (2000), however, showed that such process of state building, due to the role of low population density, could not occur in Africa, so explaining its frequent state failures. 
- Legal origins. La Porta et al. (1999) have argued that developing 'good' governance relates systematically to legal origins. Anglo-Saxon common law legal systems, in particular - which spread through colonisation, conquest and cultural influence historically developed higher degrees of judicial independence from the executive and the legislature than French civil law because landed aristocracy and merchants pursued stronger protection of property rights from the crown. Hence, common law systems supposedly deliver better protection of property rights, and a more limited, efficient state than civil law systems. Cross-section empirical evidence in La Porta et al. (1999) supports this idea, but it remains unclear whether the effect of legal origins is actually capturing the effect of some other factors (e.g., inequality).

A number of other explanations have considered geographical characteristics and political economy mechanisms. Often, the two are intertwined so that one struggles to separate the two. Such explanations highlight the following factors:

- Colonisation strategy. According to this view, the disease environment shaped colonisation strategies and, in turn, the type of governance structures in the excolonies. If settlers' mortality was high, colonisers would establish extractive institutions, because they favour the position of the extractors (Acemoglu, Johnson, and Robinson, 2001). By extension, one can argue that such ex colonies would end with states which would not pursue property rights protection or the efficient delivery of public goods. It is less immediate, instead, to conjecture the effect on bureaucratic capacity and fiscal capacity. Presumably, extractive colonial powers were interested in collecting as much revenue as they could, and to do so needed effective bureaucrats, but were not interested on developing lasting fiscal capacity or a bureaucracy that would work to develop the colonial territory. 
- Inequality. Historians Engerman and Sokoloff (2002) contend that inequality is detrimental to the emergence of legal and fiscal capacity in Latin America. Due to their factor endowments - natural resources and soil suitability for large-plantation commodities - most areas in South and Central American colonies were historically associated with high inequality. This led to oligarchic (rather than democratic) politics and exploitative institutions. In societies that began with extreme inequality, the wealthy colonial minority was both inclined and able to establish a basic legal framework that ensured them a disproportionate share of political power, and to use that influence to establish rules, laws, and other government policies that gave them greater access to economic opportunities than the rest of the population. This created states where property rights, legal systems, and fiscal institutions ensured such elite a disproportionate influence on the economy (and perpetuated the existing inequalities). Easterly (2007) extended this idea and, using agricultural endowments (the abundance of land suitable for growing wheat relative to that suitable for growing sugarcane) as an instrument for the share of income accruing to the middle quintiles or the Gini index, tested the effect of income inequality. The results show a robust inverse relationship between inequality and institutions, when using an all-embracing measure taken as the average of the WGIs.

- Structure of the economy. Economies where a substantial part of national income accrues from natural resources, and to the extent that such resources flows accrue directly to the government, have less incentive to invest in fiscal and legal capacity. Isham et al. (2004) argue that countries rich in resources extracted from a narrow geographic or economic base are predisposed to heightened economic and social divisions and have weakened institutional capacity. They also find that such countries have worse government effectiveness and rule of law, and have grown more slowly. 
Similarly, Vicente (2010) presents experimental evidence from Sao Tome and Principe supporting the hypothesis that oil increases perceived corruption along a series of dimensions.

Some recent contributions have also considered the case of economies whose structure is aid-dependent. Rajan and Subramanian (2007) document governance-dependent industries (e.g., manufacturing, as this sector rests on complex transactions between parties that require regulation and rule of law) grow more slowly in countries receiving more aid. Empirically, Busse and Gröning (2009) find that countries receiving greater amounts of foreign aid tend to have less bureaucratic and administrative capacity, as the elite may have less incentive to reform the state apparatus.

- Fractionalisation. Social divisions along ethnic, linguistic and religious lines is associated with less efficient states as the group in power tends to engage in patronage spending and decrease the production of public goods (Alesina et al., 1999). The empirical evidence has been mixed. La Porta et al. (1999) generally find no significant effects in cross-section regressions, while Alesina et al. (2003), using improved measures, find that both ethnic and linguistic fractionalisation matter for governance (less so does religious fractionalisation). The latest extension of this line of research accommodates the idea of segregation (Alesina and Zhuravskaya, 2011).

- Incentives and type of recruitment of the bureaucracy. According to this argument, the development of effective bureaucracies depends on the level of wages in the public sector relative to the private sector, which provides an incentive against corruption, and a recruitment process conditional on passing a civil service exam or attainment of a university degree. Based on data on the recent history of developing economies, Evans and Rauch (2000) find that meritocratic recruitment has a robust and positive 
effect on bureaucratic quality, but for the effect of competitive salaries there is no clear evidence.

- Political democracy. In democracies, citizens and parties enjoy substantial representation and executive power is subject to checks and balances. Hence, in such systems, incumbents will tend to promote common interests rather than using the state to retain power (Besley and Persson, 2009). Adserà et al., (2003), in a 1980-1995 panel study, present evidence that free and fair elections are associated with better governance, using ICRG data. However, the role of democracy is controversial as, historically, developmental states in Asia existed under authoritarian regimes (e.g., Taiwan and South Korea). Whether or how democracy affects state capacity remains an open question (see Lin and Nugent, 1995, p.2336).

In economics, the literature on the origins of state capacity is still relatively young. It is too early for an assessment. Here we only offer some initial thoughts. Whilst historical factors have been important for some of economies, there is no guarantee (or it is not desirable in the case of external conflicts) that history will unfold at the same way or play the same role in developing economies. With regard to geographical factors, while they can explain cross-sectional variation in state capacity, they offer little guidance to understand why states may change and have weak policy implications (as geography can hardly be changed). Political economy explanations, perhaps, are a more promising avenue to understand reforms or the inertia of state structures. The common thread to most of the proposed explanations is role of the elite. In particular, their behaviour and the type of incentives they face matters insofar as they allow investment in and accumulation of state capacity (a seminal contribution, in this respect, is Svensson, 1998). For example, Acemoglu, Ticchi, and Vindigni (2011), who also emphasise the role of economic inequality, model a specific political economy mechanism whereby, through patronage politics, the rich choose 
to distort the state structure to limit redistribution and the bureaucracy will support the elite ruling party, as the elite maintain the very state structure from which they obtain rents. An initial assessment of the role of the elite for institutional persistence is Robinson (2010), showing the usefulness of a greater understanding of how elites form and reproduce, and of how reforms influence their status. Progress on understanding the role of the elite could be quite insightful also because whether stronger states lead to development or underdevelopment may also depend on how state capacity is used (Robinson, 2002).

On the empirical side, the existing evidence finds some support for most of the factors outlined above, but also many inconclusive results. Similar to other areas of governance research, some of its determinants evolve endogenously with state capacity (e.g., inequality and the structure of the economy), so making hard to disentangle spurious correlation and causal effects. A systematic econometric analysis of the determinants of state capacity, assessing their relative importance, is missing and is a task for future research.

\section{Conclusions}

This paper has offered an overview of the strengths and limitations in current empirical research on the measurement of state capacity. The paper has also surveyed the fast emerging literature on the determinants and effects of state capacity. We have argued that existing measures on governance quality used in cross-national research can be usefully exploited to capture different aspects of state capacity. We have utilised them to provide stylised facts on its evolution. Post the end of the Cold War in the early 1990s, developing economies experienced improvements in legal, administrative and bureaucratic capacity, although the gap with advanced economies is still considerable. In some cases, the decline in cross-sectional dispersion seemed to suggest that economies with worse state capacity would catch up. In this respect, the issue of whether relatively low-capacity states remain so for 
many generations, or whether such gaps across countries are narrowing over time, is an interesting one. Evidence of convergence, or the lack of, can provide further stylised facts for future research on governance change. In fact, the academic community has not thoroughly explored the dynamics of governance measures yet, with the exception being Sobel and Coyne (2011). The issue of convergence is relevant to policy makers alike. For donor countries and development agencies, which devoted significant resources with the aim of improving governance in less developed economies, it would be of practical relevance to assess where to direct their efforts. Perhaps, if we knew that governance quality in poor economies would catch up, we would be less pessimistic about current income disparities.

Our survey of the determinants of state capacity has suggested that historical factors (such as colonial legacies) and geographical factors offer little guidance on why state capacities may change in the future, and that political economy explanations offer a more promising avenue to understand reforms or the inertia of state structures. We have argued that a better understanding of the motivations of elites to invest in state capacity provide a promising avenue of further research in why state capacities evolve differently across countries over time. One factor limiting current research is the relatively short time coverage of state capacity measures, which are persistent phenomena whose trends should be studied over the long run. Future research should concentrate on building a database of measures extending over the longest possible period, possibly in a similar fashion to existing measures of political democracy. An additional task for empirical research is a systematic econometric assessment of the determinants of state capacity. For example, in political economy explanations, the role of the elite is pivotal. Econometric analysis should also focus on the role of political democracy, which seems ambiguous. Lastly, empirical research examining its effects should also concentrate on development outcomes such as health and education, which have not received sufficient scrutiny. 


\section{Notes}

i Antonio Savoia: antonio.savoia@manchester.ac.uk; Kunal Sen: kunal.sen@manchester.ac.uk

ii Following the tradition, we use the term capacity, although semantically different from capability.

iii Incidentally, there are no clearly accepted definitions of governance. Detailed discussions of conceptual issues are in Kauffman and Kraay (2008) and Holmberg et al (2009).

iv Within the economics tradition, thorough surveys on measuring governance are Williams and Siddiqui (2008) and Kauffman and Kraay (2008). Within the public administration scholarship, an effective review of the debate on public sector performance is Van de Walle (2009).

${ }^{\mathrm{v}}$ Its appropriateness is not undisputed. Kaufmann and Kraay (2008) argue that the objectiveversus-subjective distinction is somewhat not a very useful one. Measuring governance quality always requires some degree of subjective judgement (even, for example, when selecting the elements of an objective measure). Glaeser et al (2004) argue the opposite case: objective measures are better suited to capture the concept of institutions, which by definition constrain agents' behaviour and evolve slowly.

\section{References}

Acemoglu, D. (2005). "Politics and Economics in Weak and Strong States." Journal of Monetary Economics, 52: 1199-226

Acemoglu, D. Johnson, S. and Robinson J. A. (2001) The Colonial Origins of Comparative Development: An Empirical Investigation. The American Economic Review, 91: 1369-1401

Acemoglu, D. Ticchi, D. and Vindigni, A., (2011) Emergence and Persistence of Inefficient States, Journal of the European Economic Association, 9(2): 177-208

Acemoglu, D., Vindigni, A. and Ticchi, D. (2010), Persistence of Civil Wars, Journal of the European Economic Association, 8: 664-676

Acemoglu, D., Ticchi, D. and Vindigni, A. (2010), A Theory of Military Dictatorships, American Economic Journal: Macroeconomics, 2:1, 1-42

Acemoglu, D., S. Johnson, J. Robinson, and Y. Thaicharoen (2003). Institutional Causes, Macroeconomic Symptoms: Volatility, Crises and Growth, Journal of Monetary Economics, 50: $49-123$

Amendola, A., Easaw, J. and Savoia, A. (2013) Inequality in Developing Economies: the Role of Institutional Development, Public Choice, 155(1-2): 43-60

Adserà, A. Boix, C. and Payne, M. (2003) Are you being served? Political accountability and quality of government, Journal of Law, Economics \& Organization, 19(2): 445-490 
Alesina, A. and Zhuravskaya, E. (2011) Segregation and the Quality of Government in a Cross section of Countries. American Economic Review, 101: 1872-1911

Alesina, A. Devleeschauwer, A. Easterly, W. Kurlat, S. and Wacziarg, R. (2003). Fractionalization. Journal of Economic Growth, 8: 155-194

Alesina, A. Baquir, R. Easterly, W. (1999) Public goods and ethnic divisions. Quarterly Journal of Economics 114 (4): 1243-1284

Aron, J. (2000) Growth and Institutions: A Review of the Evidence. The World Bank Research Observer, 15(1): 99-135

Banerjee, A. and Iyer, L. (2005) History, Institutions, and Economic Performance: the Legacy of Colonial Land Tenure Systems in India. American Economic Review, 95(4): 11901213

Banks, A. (1994) Cross-national time series data archive. Center for Social Analysis, University of New York, New York

Bardhan, P. (2005) Institutions Matter, but which ones?. Economics of Transition 13(3): 499532

Besley, T. and Burgess, R. (2002) The political economy of government responsiveness: theory and evidence from India. Quarterly Journal of Economics, 117(4): 1415-51

Besley, T. and Persson, T. (2011) Pillars of Prosperity: The Political Economics of Development Clusters, Princeton University Press

Besley, T. and Persson, T. (2009) The Origins of State Capacity: Property Rights, Taxation, and Politics. American Economic Review, 99: 1218-1244

Besley, Timothy, and Robinson, James A. 2010. Quis Custodiet Ipsos Custodes? Civilian Control over the Military. Journal of the European Economic Association 8, no. 2-3: 655663.

Bjørnskov C., Dreher A. and J.A.V. Fischer (2010) Formal institutions and subjective wellbeing: Revisiting the cross-country evidence, European Journal of Political Economy 26 (2010) 419-430

Bockstette V., Chanda A. and Putterman L. (2002) "States and Markets: the Advantage of an Early Start”, Journal of Economic Growth, 7:347-369

Busse M. and S. Gröning (2009) "Does foreign aid improve governance?," Economics Letters, vol. 104(2): 76-78, August.

Calì, M., and Sen. K. (2011) 'Do effective state business relations matter for economic growth? Evidence from Indian states', World Development. Forthcoming.

Cavallo E. and Daude C. (2011) "Public Investment in Developing Countries: a blessing or a Curse?”, Journal of Comparative Economics, 39: 65-81

Centeno M.A. (2002) Blood and debt: war and the nation state in Latin America. State College, PA: Penn State University Press 
Cheibub J.A., Gandhi J., and Vreeland J.R., (2010), "Democracy and Dictatorship Revisited", Public Choice, 143: 67-101

Chong A. and Calderon C. (2000) "Institutional quality and poverty measures in a cross section of countries", Economics of Governance, 1: 123-135

Collier P. (2009) 'The Political Economy of State Failure', Oxford Review of Economic Policy, Summer

Dawson A. (2010) "State Capacity and the Political Economy of Child Mortality in Developing countries Revisited: From Fiscal Sociology towards the Rule of Law, International Journal of Comparative Sociology, 51(6): 403-422

Du J. (2010) "Institutional quality and economic crises: legal origin theory versus colonial strategy theory", Review of Economics and Statistics, 92(1): 173-179

Easterly W., (2007), "Inequality Does Cause Underdevelopment: Evidence from New Instruments", Journal of Development Economics, 84: 755-776

Engerman, S. L. and Sokoloff K. L. (2002). 'Factor Endowments, Inequality and Paths of Development among New World Economies', NBER Working Paper 9259

Evans P. (1995) Embedded autonomy: states and industrial transformation. Princeton: Princeton University Press

Evans P.B. and Rauch J.E. (1999) Bureaucracy and growth: a cross-national analysis of the effects of 'Weberian' state structures on economic growth. American Sociological Review, 64(5): 748-765

Glaeser E., La Porta G., Lopez-De-Silanes F. and Shleifer A. (2004) "Do Institutions Cause Growth?", Journal of Economic Growth, 9: 271-303

Gwartney, J.G., \& Lawson, R.A. (2007). Economic freedom of the world: 2007 annual report. Available online at www.freetheworld.com

Haggard S. and Tiede L., (2011), "The Rule of Law and Economic Growth: Where Are We?", World Development 39(5): 673-685

Hendrix C.S. (2010) "Measuring State Capacity: Theoretical and Empirical Implications for the Study of Civil Conflict", Journal of Peace Research, 47:273

Herbst, J.I., (2000) States and Power in Africa: Comparative Lessons in Authority and Control, Princeton University Press, Princeton NJ

Holmberg S., Rothstein B. and Nasiritousi N. (2009) "Quality of Government: What You get", Annual Review of Political Science, 12:135-61

ICRG - International Country Risk Guide, (1997), "IRIS Database", The Political Risk Services Group, third edition

Isham J., Woolcock M., Pritchett L., and Busby G., (2005), 'The varieties of resource experience: natural resource export structures and the political economy of economic growth', World Bank Economic Review, 19, 2 
Keefer P. and Knack S. (2007) "Boondoggles, rent-seeking and political checks and balances: public investment under unaccountable governments", The Review of Economics and Statistics, August, 89(3): 566-572

Kauffman D. and A. Kraay (2008) "Governance Indicators: Where Are We, Where Should We be Going?", World Bank Research Observer, 23(1): 1-30

Kaufmann, Daniel, Aart Kraay and Massimo Mastruzzi (2009). "Governance Matters VIII: Aggregate and Individual Governance Indicators for 1996-2008”. World Bank Policy Research Working Paper No. 4978. Washington, D.C.

Knack S. and Keefer P. (1995) "Institutions and economic performance: cross-country tests using alternative institutional measures". Economics and Politics 7(3):207-228

Lin Y.L. and Nugent J. (1995) "Institutions and Economic Development", in Behrman J. and Srinivasan T.N. (eds.), Handbook of Development Economics, vol.III, Elsevier Science Mosley, P. (2010) The Politics of Poverty Reduction. Oxford: Oxford University Press

Lange, Matthew and Dietrich Rueschemeyer (eds.). 2005. States and Development: Historical Antecedents of Stagnation and Advance. Palgrave Macmillan Press.

La Porta, R., Lopez-de-Silanes, F., Shleifer, A., and Vishny, R., (1999). 'The Quality of government', Journal of Law Economics and organization, 15(1): 222-279

Mann M. (2008) “Infrastructural Power Revisited”, St Comp Int Dev 43: 355-365

Rajan R. and Subramanian A. (2007) “Does Aid Affect Governance?”, American Economic Review Papers and Proceedings, 97(2): 322-327

Rauch J.E and Evans P. (2000) "Bureaucratic Structure and Bureaucratic Performance in Less Developed countries", Journal of Public Economics, 75: 49-71

Rajkumar A.S. and Swaroop V. (2008) "Public Spending and Outcomes: Does Governance Matter?", Journal of Development Economics, 86 (2008) 96-111

Robinson J.A. (2010) "Elites and Institutional Persistence", UNU-WIDER Working Paper No. 2010/85, July

Robinson J.A. (2002) States and Power in Africa by Jeffrey I. Herbst: A Review Essay, Journal of Economic Literature, Vol. 40, No. 2 (Jun., 2002), pp. 510-519

Rodrik, Dani, Subramanian, Arvind and Francesco Trebbi (2004). Institutions rule: the primacy of institutions over geography and integration in economic development. Journal of Economic Growth, 91:131-165.

Savoia A. and Sen K. (2012) "Measurement and Evolution of State Capacity: Exploring a Lesser-Known Aspect of Governance", ESID Working Paper No.10, University of Manchester, 2012

Sen, K. and D.W. te Velde (2009) 'State Business Relations and Economic Growth in SubSaharan Africa', Journal of Development Studies 45: 1267-1283

Slemrod J. (2010) "Cheating ourselves: the economics of tax evasion", Journal of Economic Perspectives, Volume 21, Number 1, p.25-48 
Sobek D. (2010) "Measuring State Capacity: Theoretical and Empirical Implications for the Study of Civil Conflict", Journal of Peace Research, 47:267-271

Sobel R.S. and Coyne C.J. (2011) "Cointegrating Institutions: The Time-Series Properties of Country Institutional Measures”, Journal of Law and Economics, Vol. 54, No. 1, pp. 111-134

Soifer H. (2008) "State Infrastructural Power: Approaches to Conceptualization and Measurement", St Comp Int Dev 43:231-251

Soifer H. and Vom Hau M. (2008) "Unpacking the Strength of the State: The Utility of State Infrastructural Power”, St Comp Int Dev 43:219-230

Spruyt H. (2002) "The Origins, Development, and Possible Decline of the Modern State", Annual Review of Political Science, 5:127-49

Stigler G.J. and Samuelson P.A. (1968) A Dialogue on the Proper Economic Role of the State, Selected Papers No. 7, Graduate School of Business, University of Chicago, $3^{\text {rd }}$ edition

Stiglitz J. (1989) The Economic Role of the State, Blackwell

Svensson J. (1998) Investment, property rights and political instability: Theory and evidence, European Economic Review, 42(7):1317-1341, July

Tabellini G. (2005) "The Role of the State in Economic Development”, Kyklos, 58(2): 283303

Tebaldi E. and Mohan R. (2010) "Institutions and Poverty" Journal of Development Studies, Vol. 46, No. 6, 1047-1066, July

Teorell, Jan, Sören Holmberg \& Bo Rothstein. 2008. The Quality of Government Dataset, version $6^{\text {th }}$ April 2011. University of Gothenburg: The Quality of Government Institute, http://www.qog.pol.gu.se

UNDP (2009) Users' Guide to Measuring Fragility, German Development Institute, Bonn

Van de Walle, S. (2009). 'International comparisons of public sector performance: how to move ahead?' Public Management Review. 11(1): 39-56

Vicente P.C. (2010) "Does oil corrupt? Evidence from a natural experiment in West Africa", Journal of Development Economics 92: 28-38

Vom Hau, M. (2012) "State Capacity and Inclusive Development: New Challenges and Directions", ESID Working Paper No.2, University of Manchester, 2012

Williams A. and Siddique A. (2008) "The Use (and Abuse) of Governance Indicators in Economics: a Review", Economics of Governance, 9(2): 131-175

World Bank (1992) Governance and Development. Washington D.C.: World Bank.

World Bank (2011) Worldwide Governance Indicators (WGI) project. Data available at: http://info.worldbank.org/governance/wgi/index.asp 
. 0

21

23

24

26

27

29

30

32

33

34

35

36

37

38

39

40

41

42

44

45

46

47

48

49

51

52

53

54

55

57

58

59

60 